\title{
Pork food culture and sustainability on islands along the Kuroshio Current: resource circulation and ecological communities on Okinawa and Jeju
}

\author{
Sanghee Lee \\ Jeju National University, South Korea \\ Ish3966@hamail.net \\ Hyekyung Hyun \\ Center for Jeju Studies, South Korea \\ hhyun@jri.re.kr
}

\begin{abstract}
This paper investigates the formation of ecologically sustainable food systems based on pork on the islands of Okinawa and Jeju, which are located along the Kuroshio Current. Observation and interview data were informed by literature on human geography. The results demonstrated that pig-breeding space (pigsty) is key to a resource circulation system that is common to both. Other elements in the system include processes involving the butchering and distribution of pigs and a fair division of labour. This study shows a homogeneous resource circulation system through pig breeding and a pork food culture that played an important role in the formation of ecological communities on the islands of Okinawa and Jeju.
\end{abstract}

Keywords: ecological communities, islands, Jeju, Kuroshio Current, Okinawa, pork, resource circulation, sustainability

$\underline{\text { https://doi.org/10.24043/isj. } 58}$

(C) 2018 - Institute of Island Studies, University of Prince Edward Island, Canada.

\section{Introduction}

In light of warnings regarding threats to the sustainability of island life in the $21^{\text {st }}$ century, it is useful to analyse traditional food cultures in island communities along the Kuroshio Current. Communities in a similar geographic and climatic region tend to share similar ecological cultures. For example, island communities along the Kuroshio Current commonly have adapted to poor soils and harsh weather conditions such as high humidity and storms (See Youn, 2017). The pork food culture found in these island communities is among the most ecologically and culturally sustainable aspects of their existence and are the focus of the present study.

Archaeological studies suggest that wild pigs were domesticated around 6,000-10,000 BC (정 연학, 2008). Island communities in Luzon, Taiwan, Okinawa, and Jeju, which are all located along the Kuroshio Current, have achieved a form of ecological sustainability through a pork food culture. An investigation of this pork food culture is thus important for identifying a common maritime culture along the Kuroshio Current. This investigation could also have implications for future sustainable island life.

The Okinawa-Jeju region shares common extreme environmental conditions, such as infertile soil (basalt and limestone soils), a warm and humid climate throughout the year, and frequent typhoons, resulting in low crop productivity and absolute food shortage. In such 
conditions, an ecologically sustainable food system based on pork is understandable. This food culture both affected and was affected by the development of a system of social and economic resource circulation, which established these island communities as 'ecological communities' characterized by a fair division of labour and a sense of community solidarity. The islands' pork food culture is comprised of a range of practices, including the daily work of pig breeding, the butchering of pigs, the distribution of pork, and religious rituals. Comparisons between the pork food culture on Okinawa and Jeju suggest apparent cultural interactions between these islands.

This study undertakes a comparative analysis of how pork food culture influenced the growth of eco-communities on Okinawa and Jeju. In so doing, we aim to identify the ecological characteristics of the maritime culture on Okinawa and Jeju.

\section{Theories of ecology and sustainability}

This study takes and ecological perspective. The term 'ecology' was coined by the German zoologist, Ernst Haeckel, in 1866 (Stauffer, 1957). Haeckel emphasized the relationships of all animals with their organic and non-organic environments. Ultimately, ecology addresses how living organisms interact with their environments with the aim of overcoming the dichotomy between humans and nature.

The concepts of sustainability and the 'ecological community' emerged during the search for a sustainable way of life, in light of the problems of the $20^{\text {th }}$ century (including population growth, food shortages, environmental pollution, and climate change) and associated social and political issues. An ecologically sustainable community is an economic and cultural community based on the fundamental principle of an ecologically sustainable life. Biological and cultural diversities are important for sustainable island life (Clark \& Tsai, 2009). Oceanic islands can thus in some senses serve as models for ecological studies (Vitousek, 2002).

Although the objectives and perspectives associated with sustainable communities are diverse, they can be broadly divided into anthropocentric and ecological perspectives. George Marsh (1864), a pioneer in ecology research, argued for anthropocentrism in his book Man and Nature. For example, Marsh argues that because droughts and floods are inevitable when logging trees along a river in accordance with the needs of human civilization, focus should be placed on preservation of forests and soil in their original conditions. His states that humans have a moral obligation to undertake such environmental preservation and that there are economic benefits to conserving natural ecosystems. His argument contains a notion that humans are given special duties and responsibilities to manage and restore nature. Over the intervening century and a half, ecology research has diverged from this primary focus on the needs of human civilization (공명수, 2008: 2010).

In her classic The Land of Little Rain, Mary Austin (1903) sought to reconceptualize 'land ethic' in a manner that recognized the beauty and value of desert regions. She noted that all things have intrinsic value and that human and non-human beings are inter-related. This perspective requires a new understanding of nature's aesthetic values, beyond its economic values. Since nature and humans, and human consciousness and the material world are not clearly distinguished, an ecological modesty, rather than a solipsistic anthropocentrism, is required. Thus, human existence is ensured when humans and nature are closely linked. Such an ecological perspective evolved into various branches: ecological romanticism, deep ecology, cultural ecofeminism, ecological rationalism, and eco-socialism. Arne Næss (2008) has argued that recognizing the unity (or inseparability) of the ego and the outside world is key to leading a life of wisdom. As such, deep ecology claims that humans have no right to interfere with the richness and diversity of life except for the natural elements that are essential to maintaining life. This is because the nature of all life forms is inherently valuable. In assessing how human behavior affects ecosystems, evaluations should take into account 
various direct and indirect effects on society, economy, and culture as well as effects on the natural ecosystem. Næss' proposal has prompted considerable research on human interaction with nature, yet some ecologists reject what they regard as deep ecology's tendency toward mystical abstraction. Thus, for example, J.B. Callicott (1989) compares 'ecological egalitarianism' with 'ecological totalitarianism'. He argues that ecosystems have intrinsic values but also that human emotions and attitudes affect the ways in which ecosystems are treated. Mercer and Kelman (2012) value the accumulation of knowledge for adaptation through human interaction with the ecosystem. Imran et al. (2014) provide a basis for acknowledging that humans and the rest of the ecosystem are interdependent.

There have also been attempts to find solutions to today's problems in traditional life. Jackson and Palmer (2015) examine the structural transformation of natural and social relationships in today's neoliberal world. They call for a move away from assessing nature in terms of economic value and a shift toward rediscovering traditional knowledge that has accumulated through human adaptation to the natural environment. This is in part a reaction to ecosystem services and related approaches, which seek to emphasize the value of environmental goods for humans (e.g. Qiu et al., 2017; Polman et al., 2016). Similarly, Hong et al. (2013) note the contribution of traditional lifestyles to conservation of biodiversity by paying attention to the relationship between the biodiversity of Asian islands, traditional biocultural diversity, and traditional ecological knowledge. Some scholars have, however, been critical of the manner in which the discourse of sustainability and ecology sometimes overshadows or crowds out attention to other issues in island communities (Baldacchino, 2018; Grydehøj \& Kelman, 2017; Baldacchino \& Kelman, 2014), while Pugh (2018) calls for recognition of the more nuanced relationality affecting environmental processes in the Anthropocene. These various discussions are useful for examining the traditional ways of life and ecological knowledge of the peoples of Okinawa and Jeju.

We argue that the ultimate aim for a traditional island community is to create a circulation system through which the community can live safely and sustainably. 'Sustainability' generally refers to the ability to maintain a particular process or state. Sustainability as an ecological term involves an ecosystem's ability to sustain ecological functions, biodiversity, and reproduction in the future. Sustainability is being used as a generic term for many kinds of human activities today, involving human activities that are in harmony with environmental, economic, and social conditions (Miller \& Spoolman, 2009; 박길용, 2009). Sustainability in this sense was popularized by the Brundtland Report of 1987, which defined sustainability as "meeting the needs of the present and future generations without constraining the possibilities of future generations" (United Nations, 1987). Since the Rio Declaration in 1992, the concept of 'sustainability' has been applied in various fields, yet its precise meaning and practice remain unclear. Although Christine and Schmidt (2012) regard 'sustainability' as a key concept for directing societal development, they note the term's abstraction and ambiguity and use a meta-approach to analyse the various discourses that make up sustainability. Their study provides a theoretical framework for understanding sustainability at various levels, including elements, principles, processes, activities, and norms that constitute sustainability. Such discussions are useful for constructing an analytical framework for the traditional pork food culture of Okinawa and Jeju and the sustainable life of the community.

The purpose of the present study is to examine how Okinawan-Jejuan pork food culture enabled the islanders to live in an ecologically sustainable way. In addition, we examine various layers of ecological and cultural characteristics in a single oceanic cultural sphere formed by the Kuroshio Current. We furthermore investigate the characteristics of island and marine culture more generally by considering the similarities and differences between Okinawa and Jeju. In this way, it is possible to uncover interrelationships between islands, as noted by Stratford et al. (2011). 
The research methods used in this study involve literature research, observational research, and interviews. Literature research was conducted to identify the origins and general historical trajectories of Okinawan and Jejuan pig breeding. Observations and interviews are used to investigate Okinawan and Jejuan pork food culture and ecological life.

Several comparable categories and analytical frameworks are needed to determine whether the traditional pork food culture of Okinawa and Jeju are associated with the formation of an ecological community. Categories such as space, process, relationship, utilization, and norms are considered. Hence, we will consider: 1) the formation of a circulatory system of pig breeding and ecological space and resources, 2) the process of disassembling and distributing pork, 3) community solidarity and the resource allocation process, 4) the formation and utilization of a food circulation system through the combination of pork and other foodstuffs, and 5) how pig farming and its ritual relationship with pork food culture affects ecological norms and values.

\section{Pigs and the environment on Okinawa and Jeju}

Okinawa and Jeju are relatively remote islands in Japan (Okinawa is approximately 1,500 km from Tokyo) and Korea (Jeju is approximately $450 \mathrm{~km}$ from Seoul) (see Figure 2). Although their residents are of different nationalities and ethnicities, Okinawa and Jeju are both islands in the Kuroshio Current. Both islands have a subtropical climate that is hotter than their respective mainlands. Okinawa is near the southern boundary of the subtropical climate zone, whereas Jeju is close to the northern boundary of this climate. Both islands are in the path of typhoons and are characterized by windy and rainy weather. The islands are composed predominantly of basalt and limestone with numerous caves. Due to poor soil fertility and water scarcity, a limited number of grains (mainly barley, foxtail millet, and soybeans) and sweet potatoes are cultivated and used for food.

The islands have similar histories: They were once independent countries but were ultimately annexed by the governments of their respective mainlands. After losing their independence, they were given new names: Okinawa was formerly the Ryukyu Kingdom, and Jeju was formerly the Tamla Kingdom. During World War II, residents on both islands were forced to build military bases for the Japanese Imperial Army. Large portions of the populations on both islands were also slaughtered by their respective governments during the battle of Okinawa in 1945 and Jeju 4 April massacre in 1948.

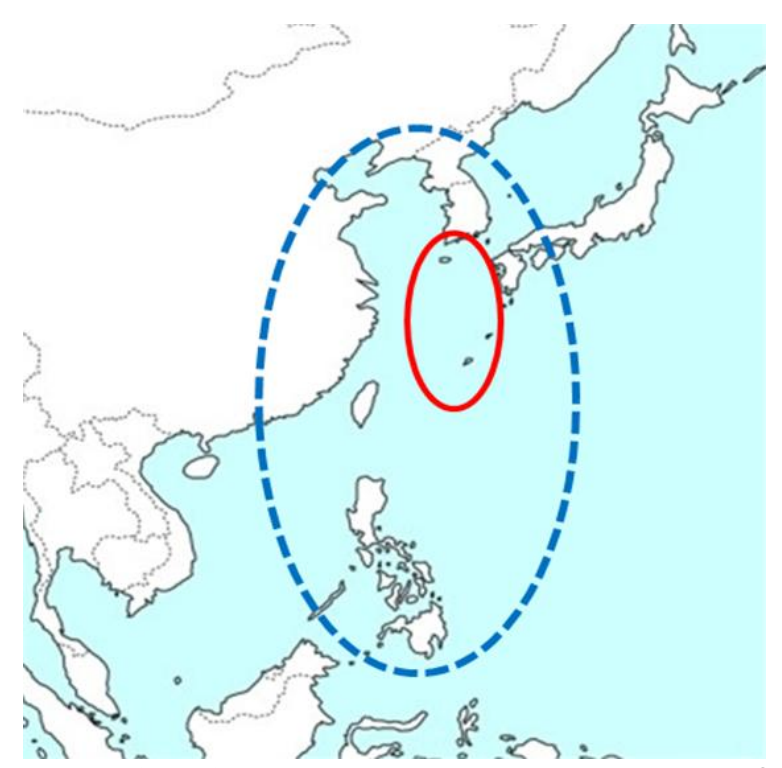

Figure 1: Dung-eating pig cultural area of the Kuroshio Current. (C) Hyekyung Hyun) 


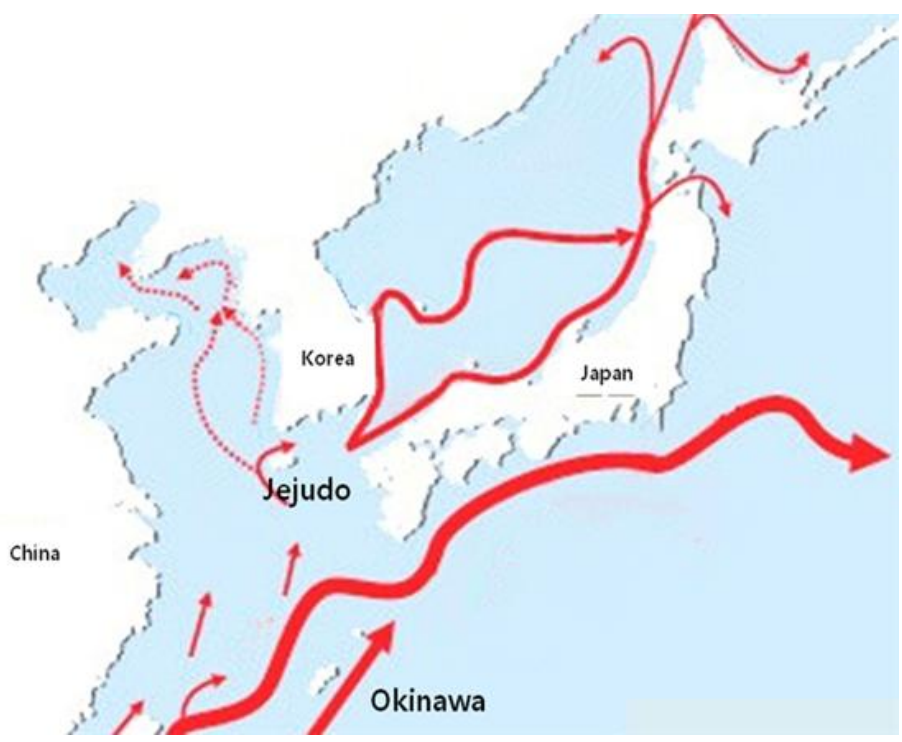

Figure 2: Okinawa and Jeju along the Kuroshio Current. (C) Hyekyung Hyun)

In terms of food culture, both islands are known for their 'dung-eating pigs' and pork food dishes. The word for 'pig' in the local dialects is wa on Okinawa and dosegi on Jeju. There are also several local terms for pig and pork products on these islands. In addition, due to increased shipments of flour to Japan and Korea during the US military occupation just after World War II, pork noodle dishes using pork bone soup became popular on the Japanese and Korean mainlands, causing the distinct pork food culture of these islands to become more widely known.

It is possible to estimate the time when pig breeding began on Okinawa and Jeju based on documentary evidence. The records of Chinese investiture envoys from 1756 provide important information regarding food during the age of the Ryukyu Kingdom, specifically between 1534 and 1866. These documents note in 1534 that "wild boar meat is available everywhere, but poor people cannot afford it" and that pigs were presented to Chinese investiture envoys as gifts for their parties. These records indicate that pork was not available to ordinary residents on Okinawa during this period (Munetaka, 2005).

The Annals of the Joseon Dynasty 조선왕조실록 (a chronological record of the reign of 25 kings during Korea's medieval period) is another important source of information on pigs and pork on Okinawa. People who drifted from Korea to Okinawa (and anywhere outside of Korea) on the sea and back were routinely investigated by government officials, and the details of such investigations were recorded in the annals. The record includes Jeju fishermen who drifted to Okinawa and interacted with Okinawa's culture. For example, in the $8^{\text {th }}$ year of the reign of King Sejo 세조 in 1462, it was recorded that Yang and others from Jeju said "there are no animals on Okinawa, only pigs." From this record, it could be said that pigs were already familiar to people on Okinawa. Similar statements about pig breeding were given by Kim and others. Nonetheless, it appeared that pork was not widely available until at least the $17^{\text {th }}$ century. Since the $18^{\text {th }}$ century, pork has been documented as the main food accompanying funerals and other important ceremonies attended by ordinary people. This finding would mean that pig farming was on the rise in the $18^{\text {th }}$ century. With an increase in the cultivation of sweet potatoes (used for pig feed in the $19^{\text {th }}$ and early- $20^{\text {th }}$ centuries), it was rare to find households on Okinawa that did not breed pigs (Munetaka, 2005).

In the case of Jeju, the Records of the Three Kingdoms: Book of Wei Biographies of the Wuhuan, Xianbe, and Dongyi 삼국지 위서 동이전, written in $280 \mathrm{AD}$, states that "the 
people of Jooho 주호 (Jeju) are good at breeding cattle and horses." It could therefore be said that pig breeding may have started during the early Tamla Kingdom (227 BC-1402 AD) (진영 일, 2008, pp. 42-43; Youn, 2017). A record of pig breeding in public institutions on Jeju can be found in Won-jin Lee's Tamlaji 탐라지, written in 1653 (김찬흡, 2002). During the Japanese colonial period (1910-1945), it was written that "there were few houses without pig farming" on Jeju (강동식 et al., 2009).

The relationship between sweet potatoes and pig farming on Okinawa and Jeju was very important in commercial terms, and it seems that the breeding of dung-eating pigs on Okinawa and Jeju was established to compensate for insufficient pig feed. A new type of ecologically sustainable food culture came to be established, and, in the process, the pork food culture of the islands along the Kuroshio Current zone was formed.

\section{Breeding dung-eating pigs and the formation of an ecologically sustainable community}

The pigsty: a critical space in ecologically sustainable resource circulation

In examining Okinawan-Jejuan pork food culture, space for breeding pigs is the most remarkable aspect from an ecological perspective. All spatial arrangements reflect a value system in addition to utilitarian physical considerations. Until the early 1980s, homes on Okinawa and Jeju had a separate space for housing dung-eating pigs.

The Kuroshio Current flows past the southeastern part of Jeju, the southwestern part of Kyushu, and Okinawa. In these areas, a typical private house consisted of a main building, with a kitchen, a pigsty, and a vegetable garden, all detached from the main building. Such houses are more common in the southeastern part of Jeju (in contrast to the northwestern part) (윤일이 \& 尾道建二, 2010). This suggests the influence of a culture to the south that was brought northward by the Kuroshio Current. Similarly, traditional private houses on Okinawa are equipped with a separate kitchen, a pigsty, and a vegetable garden, together with the main accommodation building, called a woohuya.

The southern culture in question is the culture of Southeast Asia and southern China, linked by an ocean route. The function of the detached kitchen is to prevent damage caused by frequent typhoons and to keep the kitchen cooler in the hot and humid climate. The fireplace in the kitchen is worshiped (the faith of fire) and is viewed as a southern cultural element spread along the Kuroshio Current (Youn, 2017). Because the kitchen functions as a food preparation space, a work space, and a dry space, kitchens on Jeju and Okinawa are relatively large in size.


Figure 3: Pigsty latrines ('pig toilet') from Okinawa (Huru, left, (C) Sanghee Lee) and Jeju (Tongsi, right, C Hyekyung Hyun).

The pigsty latrine (a toilet over a pigsty, or 'pig toilet') is a southern cultural element that spread along the Kuroshio Current from the Philippines and is used to protect against 
the venomous snakes common in hot regions (김광억, 1988; 장보웅, 1974, 1981). As shown in Figure 3, the external structure of the pigsty latrine (known as huru on Okinawa and tongsi on Jeju) consists of an upper part and a lower part. The upper part is the toilet, and the lower part is the pigsty. In the pigsty, the pig's activity space, house (or sleeping space), feeding space and manure space are separate. The structure, which is usually elliptical, increases hygiene and provides effective protection from snakes.

These house structures exist in areas along the Kuroshio Current (김광억, 1988; 장보웅, 1974: 1981; Youn, 2017). To date, however, the possibility that this type of private house is connected to a resource circulation system has not been analysed. These pigsty latrines are good examples of a resource circulation system when we analyse the combines functions and roles of a kitchen, a pigsty, and a vegetable garden. Vegetables produced in the garden are circulated and consumed through the kitchen, and leftover food and human feces become pig feed. In turn, the pig feces are reused as manure and become an important natural fertilizer in the vegetable garden. Thus, this type of house is useful in forming an ecological resource circulation system, and the pigsty connects the end of consumption to the production in the ecological circulation system.

According to our investigation, in 2011 and 2012, an average of over 30 types of crop were cultivated in the garden of each house (ataiga in the local dialect of Okinawa and wooyoung on Jeju) and were used to prepare over 100 distinct dishes. Chinese cabbage (Brassica rapa) in particular was cultivated throughout the year. The perennial green vegetables benefit from the warm and wet climate, and when combined with scarce grains, meat, and fish, they expand the otherwise meager food supply. Moreover, the formation of the garden-kitchenpigsty resource circulation system reduces energy consumption in the ecological space.

Residents of these islands are cautious about altering the spatial structure in a way that interferes with this ecological system. The pigsty is the most important element. The people of Okinawa and Jeju believe that a deity dwells in the pigsty. On Okinawa, this deity is called Hurunukami ('The Deity of the Toilet'), the most prestigious among the household deities and the one who can expel evil spirits. After attending a funeral, people stop at the pigsty to expel possible evil spirits before entering their main house building. Similarly, people on Jeju believe that there is a deity named Chikdobuin ('The Toilet Wife'), and when a pigsty is altered carelessly, they believe that the household will face a series of unfortunate events. Thus, the existence and power of the deity of the pigsty is a cultural feature seen on multiple islands along the Kuroshio Current.

The breeding of dung-eating pigs was reported in the Philippines, Okinawa, the Korean Peninsula, and China's Shandong and Shanxi provinces in the 1940s (석주명, 1968). More recently, Nemeth (1987) reported that dung-eating pigs could be found in equatorial South Asia, Africa, Central America, and China. However, it is significant that, on Okinawa and Jeju, the pigsty is not only a place for breeding pigs but also serves as part of a system that circulates the island's resources. The pigsty also became part of a cultural system.

\section{The division of labour in pig breeding and butchering processes}

An ecological community seeks sustainability through decision-making among community members concerning resources and through the equitable division of labour and distribution involving these resources. The breeding, slaughtering, butchering, and distribution of pigs on Okinawa and Jeju affected the formation of this ecological community. Pig slaughtering and pork distribution are not practiced routinely but are instead performed in association with important personal, familial, and community ceremonies and events. The community thus recognizes the successful breeding of a pig as very important labour.

In the local division of labour, breeding pigs is the responsibility of women, whereas 
slaughtering, butchering, and distributing them are the responsibilities of men. The most important concern in pig breeding is to produce fat pigs, which are regarded as one of the highest virtues for housewives. It is deemed praiseworthy for a housewife to present a wellfed pig at the funeral of a parent-in-law on Jeju because this is regarded as an expression of deep condolence (강수경, 2011). As such, it is very important for women and children to collect food scraps because pig feed is very scarce.

Distributing pork after slaughtering and butchering pigs is regarded as men's work. In particular, men are prominently involved in setting the date of slaughtering, choosing a pig for slaughter, the slaughtering itself, butchering, and distributing the pork. A butcher (called wakurusa on Okinawa and youngin on Jeju) plays the lead role in slaughtering and butchering, but men from the community generally join in this task. Sigeji (1995) comments that most Okinawan men could be regarded as a wakurusa on some occasions because most of Okinawa's private households engage in breeding pigs.

The process of slaughtering and butchering a pig is called wakurusi on Okinawa and dotchuryeom on Jeju. The slaughtering process for pigs is similar on Okinawa and Jeju, but the cuts of meats are different (Figure 4). The slaughtering is performed as follows: When a pig is chosen for slaughter, the slaughtering and butchering are performed with the participation of village residents and relatives. For several days before the slaughter, the pig is prevented from consuming human feces. Food is limited to sweet potatoes or is withheld to clear the pig's gut. On the day before or the day of the slaughter, the pig is tied up and taken out of the pigsty. Rags are inserted into the pig's mouth, and the mouth is tied tightly so that no cries can be heard. The pig is either hung from a tree for a day to slowly strangle or is throttled to death with wire. The blood is removed before the butchering. The pig is stripped of hair using fire and knives prior to butchering.

The butchering is performed where water is close at hand because a considerable quantity of water is used. Therefore, the butchering is often performed near a beach. The butchering process can be divided into approximately five steps: the removal of hair, blood, internal organs, bone, and meat (including fat). As the butchering process is a community effort, the pig's hair is sold to raise community funds.

Afterward, the internal organs are washed to clean them inside and out. On Okinawa, most of the internal organs are chopped and salted and stored in a jar. The blood, liver, kidney, pancreas, and head are not preserved in salt but are consumed on the day of slaughter (Munetaka, 2005). On Jeju, the parts that are eaten raw or steamed are separated. The womb, spleen, an intestinal fat called maerok, and fat under the chin called solbadi are eaten raw. Other parts are steamed. The participants share the liver and intestines alongside alcoholic beverages (강수경, 2011).

Pig butchering differs between Okinawa and Jeju, as shown in Figure 4. These differences may reflect different ways of combining other food resources on each island and different forms of community meal (members can eat at different times of the day, for instance during a daylong party). Pork is distributed equitably among the island's community members. On Okinawa, the owner of the pig takes all the meat and stores it to continue to share it with neighbours. On Jeju, the owner takes the intestines, the head, and the bones between the head and ribs (jeobjakppyeo) after paying the butcher (yongin) for his work by offering him the anal parts, bladder, and hair. The remainder is distributed among community members in a community meal.

On Okinawa and Jeju, pork is spoken of as part of the culture of the community meal of 'making together and eating together'. The meaning of the community meal includes distributing pork to every community member. On both islands, the eating of pork at the community meal occurs at every family memorial, seasonal ceremony, and community ritual. The community meal is based on boiled pork. 


\begin{tabular}{|l|l|l|}
\hline Cuts of pork on Okinawa & Cuts of pork on Jeju \\
\hline Cut & Okinawa & Myeori (head) \\
\hline (a) & Mimika (ear) & Soldeui (bottom of head and neck) \\
\hline (b) & Chiraga (cheek) & Llrun (backbone) \\
\hline (C) & Kuchama (neck) & Jeobjakppyeo (neck and shoulder bones) \\
\hline (d) & Udeaka (neck) & Galli (rib) \\
\hline (e) & Gu-ya-nuji (shoulder) & Galli (rib) \\
\hline (f) & Bo-jisi (sirloin) & Jeongak (shoulder) \\
\hline (g) & Uchinagani (tenderloin) & Jeongak (shoulder) \\
\hline (h) & Haraga (belly) & Sung (belly) \\
\hline (i) & So-ki (rib, sparerib) & Sung (belly) \\
\hline (i) & Chibijiri (fresh meat) & Bipi (hip) \\
\hline (1) & Juju (tail) & Hugak (hind leg) \\
\hline (1) & Dibichi (pig's feet or trotter) & Hugak (hind leg) \\
\hline (im & & \\
\hline
\end{tabular}

Figure 4: Butchering a pig on Okinawa and Jeju. (C) Hyekyung Hyun)

On Okinawa, pork is considered special at ceremonies. In seasonal ceremonies such as a New Year's celebration, it is important to distribute pork among community members. The New Year's pig (syouguwachiwa) is slaughtered and shared with relatives and neighbours. This pig has been slaughtered between November and December in the lunar year of the previous year. In a New Year's celebration on Okinawa, pork occupies an important position, whereas eating rice cakes is important on the mainland. This community meal includes praying for the safety of the family, health and prosperity for future generations, and richness of life. On New Year's Eve, soki soba (Okinawa soba with spare ribs, see Figure 5) is consumed, and a stew of internal organs (consisting of kubu irichi and intestines) is eaten on New Year's Day. $K u b u$ irichi, which is a stir-fried dish made with konbu seaweed, means 'to be pleased'.
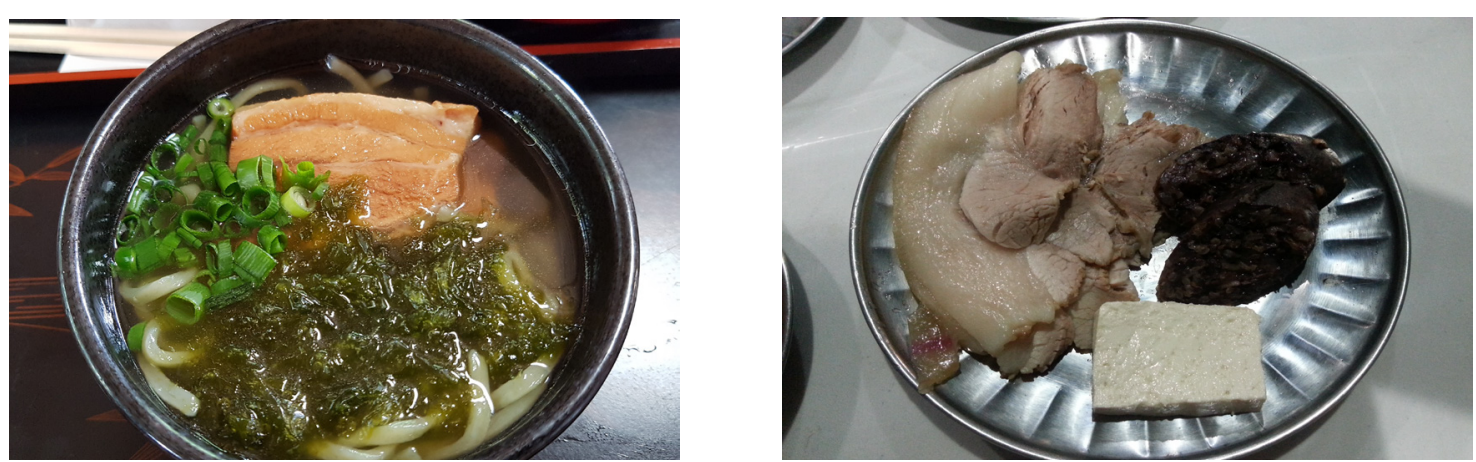

Figure 5: Pork-based ceremonial food on Okinawa (Soki soba, left, C Insil Yang) and Jeju (Gogi-ban, right, (C) Sookyung Kang). 
On Jeju, someone who distributes pork at a ceremony is called a dogam. The dogam divides boiled pork into parts based on their use. The role of the dogam is to distribute the limited amount of boiled pork fairly to community members. The dogam distributes several pieces of meat, maleun dumbi (dried hard tofu), and sundae (a sausage made of blood and bean curd stuffed into pig intestine), which are collectively called gogi-ban (meaning 'meat tray', see Figure 5). Even the owner who provides the pig must obtain permission from the dogam to obtain a gogi-ban. The expression on Jeju meaning 'distributing bans (trays)' means that those meat trays are being fairly distributed. 'Eating day' refers to the day of a ceremony on which pork dishes will be expected.

The eating of pork during a community meal is an important social activity on Okinawa and Jeju. If a member fails to participate in or misses the community meal, it is treated as a very serious social issue. Distributing pork is an opportunity to provide community members with needed protein and vitamin B1, and this community meal is integral to the shared sense of community. In addition, to maintain the ecological community, labour must be shared continuously; hence, solidarity through the community meal becomes an important social activity for maintaining the community.

Food associated with pork and the formation of the food circulation system

The breeding of dung-eating pigs has played an important role in establishing the food circulation system of the islands. Pig breeding generates manure for the island's infertile volcanic soil. The acidic pork that is obtained, combined with alkaline foods such as grains and seaweeds, creates a balanced food mix. The food culture of pork combined with grains, seaweed, and vegetables can be seen specifically on the islands connected by the Kuroshio Current.

One basic common aspect of the food of Okinawa and Jeju is the use of various combinations of barley, soybeans, grains, fish, seaweed, meat, and vegetables to produce dishes. Based on the warm and humid climate of the Kuroshio Current, a food circulation system can be broadened by the supply of scarce carbohydrates and protein resources through the combination of perennial green vegetables and abundant seaweed. This diversified food circulation system has made it possible to sustain the survival and labour of community members and thus maintain their island communities. According to 오영주 (1999), the cuisines of Okinawa and Jeju consist of 150 dishes and 450 dishes respectively. These numbers of dishes exceed those in rice farming regions, including those on each island's respective mainland. The increased variety of dishes can be seen as a strategy by islanders to survive food crises. On Okinawa and Jeju, pork is involved in many recipes, utilizing every part of the pig, from head to tail, including the intestines and blood. The following are typical traditional foods that are made with pork on Okinawa and Jeju.

Pork dishes on Okinawa and Jeju are based on boiled pork. Stews and soup dishes utilize stock from the making of boiled pork. The development of stews and soups is related to the size of the community. Pork is a precious ingredient, and it is not possible to distribute sufficient amounts of pork meat to all community members. Therefore, pork is inevitably provided in the form of stews and soups to provide a sufficient amount to everyone. Stews and soup dishes are not based on one ingredient but rather on a combination of several ingredients (barley, soybeans, grains, fish, seaweed, and vegetables).

Pork is effective in increasing the total amount of food that can be distributed to community members through various combinations of ingredients. Combinations such as meat and grains, meat and seaweed, meat and vegetables, and meat and fish are the most basic forms of pork dishes. More complex combinations such as meat/grains/vegetables, meat/grains/seaweed, and meat/seaweed/vegetable might have been developed later. Therefore, these pork dishes can be understood as illustrating the development of cooking methods to feed families and village communities during the community meal. 
On Okinawa, soup dishes such as soku-jiru (pork rib soup), nakami-jiru (pig intestine soup), and tebichi-jiru (pig's feet soup) were developed. On Jeju, pork soup with cabbage, mom-guk (pork soup with gulfweed and buckwheat powder), and bracken soup (pork soup with bracken) emerged. Mom-guk and bracken soup are typically consumed during ceremonies. All these thick pork soups are based on stock created by boiling pork bones for hours. The benefits of providing pork in the form of various soup dishes are that it (1) stabilizes the food supply, (2) promotes community nutrition, and (3) creates an ecological circulation system.

Unlike on Jeju, Okinawans have developed stewed and stir-fried dishes that tend to be attributed to the influence of Okinawa's historical exchanges with China's Fujian Province and Taiwan, which are also located along the Kuroshio Current. Okinawa was a gateway to Far East Asia, and the influence of Southeast Asia (such as the Philippines and Indonesia) via the Kuroshio Current would therefore be understandable. Chanpuru (an Okinawan stir-fry dish) is a good example.

In the hot and humid climates of Okinawa and Jeju, pork is marinated using salt or soy sauce for preservation purposes. On Okinawa, pork is marinated in salt for preservation for a few months and is consumed gradually at ceremonies. On Jeju, pork is kept in a pot filled with soy sauce to preserve it for relatively short periods. One characteristic of the food culture of the Kuroshio Current is the use of sauce combinations for soup with soy sauce made from soy beans and salt, with salted and fermented seafood, and with salt harvested from the beach. This practice is also present on both Okinawa and Jeju.

\section{Community rituals and pig sacrifice}

Community rituals have influenced the formation of community values and identities through disciplines (or rules) that are observed during rituals. These rituals are important for binding communities, especially on islands. Rituals exert power in the divine rather than the secular realm. Elements of rituals include sacrificial acts and procedures, taboos, and foods. The slaughtering of animals and the offering of them to a deity is generally called 'sacrifice', which appears worldwide as a ritual for connecting spiritual beings with humans (Sahito, 2008). In rice farming areas, rice offerings are common. Even when meat offerings occur, the community meal is often more important than the act of sacrifice itself. However, on islands such as Jeju and Okinawa, pig sacrifice has been widely practiced. It should be noted that pig sacrifice during rituals is widely observed on other islands along the Kuroshio Current as well.

On Okinawa and Jeju, offerings consist of pork rather than beef or chicken. Therefore, a community ceremonial feast is a recognition of the pig as a mediator between humans and nature (or a deity) and is a part of applying an ecological cultural system. On Okinawa, in festivals or ceremonies such as Seimei Matsuri (on the Autumnal Equinox or Shimi in the local language) and Higan Matsuri (a week around the Spring and Autumnal Equinoxes), a box containing usannmi (three dishes) is offered on an altar. Three animals, including a pig, are sacrificed and offered to a deity. During these rituals, Okinawans pray for health, safety, and protection from misfortune for their families.

On Okinawa, the female shaman in the local religion of Ryukyu Shinto is called an utah. The utah receives new births and serves an individual, family, or village. In this religion, people can eat only pork and chicken because they cannot eat animals that could be a god's envoy. This suggests that the beliefs of Okinawans are closely related to pig breeding. The utah performs a pig sacrifice on various occasions, such as annual ceremonies, funerals, construction rituals, and disaster prevention rituals (Sahito, 2008). On Okinawa, sacrifice appears in a variety of forms depending on whether it is commissioned by a village, a family, or an individual. In rural Okinawa, there is a tradition of awakening the pigs to expel evil spirits or sacrificing a pig to prevent the spread of a pandemic. 
Community rituals related to pigs on Jeju consist of shamanic rituals (dottje) and the Confucianism festival, a village ritual. Each village on Jeju contains various shamanic shrines. Villagers believe that shamanic deities protect their lives. Therefore, if a member of a village holds a congratulatory or condolatory ceremony, he or she will go to a shrine to offer pork to a deity so that the ceremony can be performed safely. On such an occasion, a large ceremony is held to offer a whole raw pig as part of a dottje. Offering an entire pig to a deity has symbolic meaning.

During a dottje, a female shaman associated with a shrine speaks in detail to her deity about why the ceremony was commissioned and about the commissioner's process of offering pork and pig parts before praying for blessing. During this process, the pork is qualified as a sacred sacrifice to the deity, and it becomes a mediator for praying to the deity for good fortune. After the dottje, the pork is shared by community members. The sharing of sacrifices is regarded as a process not only for affirming the sense of solidarity in a village but also for bringing about the blessing of individuals and groups. The eating is regarded as a process in which a positive image of pigs is propagated and internalized by community members and as a process of recognizing pigs as a medium for creating human happiness. The village ritual on Jeju is practiced from the first month of the Lunar New Year until March. During a village ritual, one male pig is sacrificed. The blood and hair that are collected are offered on an altar. After the hair and intestines are removed, the raw pork is offered. Such village rituals are performed by village men in the style of Confucianism. Because men play the central role in handling pork during the ritual, this task connects the cultural value of meat with men.

At the end of the ritual, pork is distributed to everyone in the community. It is believed that the person eating this pork will experience one year without any misfortune or disease. The most important value in the lives of the islanders is the promotion of survival through the effective mobilization of labour. Eating pork improves nutrition and involves a cognitive process of recognizing the body as free of disease through protection from evil spirits.

Different forms of sacrifice are practiced on Okinawa and Jeju, but these commonly involve the following: (1) the slaughter of an animal, (2) an offering to a deity, and (3) a feast for participants. In this process, pig sacrifice is considered payment for a deity's protection. Pigs are thus a positive symbol in public ceremonies. Globally, some traditional cultures view pigs in a positive light, whereas others do not. Positive views of pigs include their being sacred sacrifices to the heavens and messengers of god. Negative images of pigs include their perception as symbols of greed, laziness, or uncleanliness (김종대, 2008). However, in community ceremonies on Okinawa and Jeju, pigs have a strongly positive image as the deity's messenger, a bringer of blessings and safety, and an amulet. This positive image has permitted the development of close human-pig interactions and made it possible to recycle pig feces as manure and to build an ecologically sustainable resource circulation system.

\section{Conclusions}

The islands of Okinawa and Jeju are well known for their pork food culture. Although the origins and development of the local pork food culture have been studied for each island, previous studies have not taken into account the regional ocean currents and maritime culture. Thus, the pork food culture on one island would have been understood only as the isolated culture of an isolated island. The Second World War and the Cold War in the $20^{\text {th }}$ century as well as nationalism have impeded attempts to understand the island cultures of the Kuroshio Current. As noted earlier, however, island spaces are inter-related (Stratford et al., 2011), and it is humans who construct understandings of inter-island relationships (Lee et al., 2017). The pork food culture discussed in the present study can be understood as a product of a cultural network along the Kuroshio Current. 
The existence of a shared maritime culture along the Kuroshio Current is beginning to be recognized. Without this recognition, the pork food culture would still be understood as the unique food culture of each island. Fortunately, research on the origins and development of the pork food culture on Okinawa and Jeju has begun. This research demonstrates (1) that the pork food culture on Okinawa and Jeju is exogenous rather than endogenous, (2) that the pork food culture was spread via the Kuroshio Current, (3) that the pork food culture was conditioned by the local ecology, and (4) that the island communities accepted the pig culture based on an ecological rationale.

The communities of Okinawa and Jeju made pigs part of their islands' broader resource circulation system. This process involved pig breeding and pork distribution, the division of labour, and the expansion of the food circulation system through the combination of food ingredients. Community belief and rule systems were also formed through the sacrifice of pigs to the deities. This study has focused on human attitudes toward creating the ecological system of the island community through the pork food culture of Okinawa and Jeju, which is characteristic of the pork food culture found along the Kuroshio Current.

\section{References}

\section{References in English}

Austin. M.H. (1903). The land of little rain. Boston \& New York: Houghton Mifflin.

Baldacchino, G. (2018). Seizing history: development and non-climate change in Small Island Developing States. International Journal of Climate Change Strategies and Management, 10(2). https://doi.org/10.1108/IJCCSM-02-2017-0037

Baldacchino, G., \& Kelman, I. (2014). Critiquing the pursuit of island sustainability: blue and green, with hardly a colour in between. Shima, 8(2), 1-21.

Callicott, J. B. (1989). In defence of the land ethic: Essays in environmental philosophy. Albany, NY: SUNY press

Christen, M., \& Schmidt, S. (2012). A formal framework for conceptions of sustainability: a theoretical contribution to the discourse in sustainable development. Sustainable Development, 20, 400-410. https://doi.org/10.1002/sd.518

Clark, E., \& Tsai, H. M. (2009). Ecologically unequal exchange and landesque capital on Kinmen island. Asia-Pacific Forum, 44(2), 148-167.

Grydehøj, A., \& Kelman, I. (2017). The eco-island trap: climate change mitigation and conspicuous sustainability. Area, 49, 106-113. https://doi.org/10.1111/area.12300

Hong. S.K. (2013). Island bio-cultural diversity and traditional ecological knowledge. Journal of Marine and Island Cultures, 2(2), 57-58. https://doi.org/10.1016/j.imic.2013.11.005

Imran, S., Alam, K., \& Beaumont, N. (2014). Reinterpreting the definition of sustainable development for a more ecocentric reorientation. Sustainable Development, 22, 134-144. https://doi.org/10.1002/sd.537

Jackson, S., \& Palmer, L.R. (2015). Reconceptualizing ecosystem services: possibilities for cultivating and valuing the ethics and practices of care. Progress in Human Geography, 39, 122-145. https://doi.org/10.1177/0309132514540016

Lee, S. H., Huang, W. H., \& Grydehøj, A. (2017). Relational geography of a border island: local development and compensatory destruction on Lieyu, Taiwan. Island Studies Journal, 12(2), 97-112. https://doi.org/10.24043/isj.33

Marsh, G. (1864). Man and nature; or, physical geography as modified by human action. New York: Charles Scribner.

Mercer, J., Kelman, I., Alfthan, B., \& Kurvits, T. (2012). Ecosystem-based adaptation to climate change in Caribbean small island developing states: integrating local and external knowledge. Sustainability, 4(8), 1908-1932. https://doi.org/10.3390/su4081908 
Miller G.T. Jr., \& Spoolman, S.E. (2009). Living in the environment: principles, connections, and solutions. Belmont: Brooks/Cole.

Munetaka, H. (2005). Pork country: Okinawa. Japan: Seiindo.

Næss, A. (2008). Ecology of wisdom: writings by Arne Næss. A.R. Drengson \& B. Devall (Eds.). Berkeley: Counterpoint.

Nemeth, D.J. (1987). Architecture of ideology: Neo-Confucian imprinting on Cheju island, Korea. Berkeley: University of California Press.

Polman, N., Reinhard, S., van Bets, L. K., \& Kuhlman, T. (2016). Governance of ecosystem services on small islands: three contrasting cases for St. Eustatius in the Dutch Caribbean. Island Studies Journal, 11(1), 245-264.

Pugh, J. (2018). Relationality and island studies in the Anthropocene. Island Studies Journal, forthcoming. https://doi.org/10.24043/isj.48

Qiu, S., Yue, W., Zhang, H., \& Qi, J. (2017). Island ecosystem services value, land-use change, and the National New Area Policy in Zhoushan Archipelago, China. Island Studies Journal, 12(2), 177-198. https://doi.org/10.24043/isj.20

Sahito, H. (2008). Diversity of Japanese Okinawa sacrifice. Journal of Chung-Ang Folkloristics, 13, 41-61.

Sigeji. M., \& Nam. E. W. (1995). The secret of Japanese longevity: Okinawa longevity village. Seoul: I-GU Publishing.

Stratford, E., Baldacchino, G., McMahon, E., Farbotko, C., \& Harwood, A. (2011). Envisioning the archipelago. Island Studies Journal, 6(2), 113-130.

Stauffer, R.C. (1957). Haeckel, Darwin, and ecology. Quarterly Review of Biology, 32, 138 144. https://doi.org/10.1086/401754

Youn L.L. (2017). Private houses in the east china sea culture: understanding the traditional architecture of Jeju, Kyushu, Ryukyu and Taiwan. Seoul: Sanjini.

United Nations (1987) Our common future: Brundtland Report. Oxford: Oxford University Press. Vitousek, P.M. (2002). Oceanic islands as model systems for ecological studies. Journal of Biogeography, 29(5-6), 573-582. https://doi.org/10.1046/j.1365-2699.2002.00707.x

References in Korean

강동식. et al. (2009). 『일제 강점기 제주지방행정사』. 서울: 가이드.

강수경. (2011). 『제주지역 돼지고기 음식문화의 전통과 변화: 의례 음식에서 일 상음식, 향토음식으로』. 제주: 제주대학교.

공명수. (2008). 「생태도시의 조건」 . 포천신문』 (http://www.ipcs21.com).

공명수. (2010). 『생태학적 상상력과 사회적 선택』. 서울: 동인.

김광억. (1988). 「성인식: 의례적 구조와 문화적 의례」.『정신건강연구』, 7, 19-42.

김종대. (2008).「돼지를 둘러싼 민속상징, 긍정과 부정의 모습」.『중앙민속

학』, 13, 63-74.

김찬흡. (2002). 『역주 탐라지』. 서울: 푸른 역사.

박길용. (2009). 『현대환경학』 대영출판사.

『조선왕조실록』 세조 8년 기사

석주명.(1968).『제주도수필집』. 서울: 보진재.

오영주. (1999).『제주향토음식문화와 투어리즘』. 제주: 제주학회.

윤일이, 尾道建二 (2010). 동중국해권 민가의 聖域에 관한 연구. 문화재, 43, 60-81.

장보웅. (1981).『한국의 민가 연구』. 서울: 보진재.

장보웅. (1974). 「제주도 민가연구」.『대한지리학회지』, 9, 13-31.

정연학. (2008). 「중국의 돼지문화」.『중앙민속학』, 13, 7-39.

진영일. (2008). 『고대 중세 제주역사 탐색』. 제주: 제주대학교 탐라문화연구원. 